\title{
The Optimum Dose of Beta-Glucan for Stimulating Peripheral Blood Mononuclear Cells (PBMCs) to Produce Cytokines: In Vitro Study
}

\author{
Meira Erawati
}

Faculty of Medicine, Diponegoro University

\section{ABSTRACT}

Background: Beta-glucan has been frequently used in laboratory trials as an immunomodulator in both in vivo and in vitro studies, but the effective dose for measuring its performance has not been established. Like other immunomodulators, researchers must establish the right dose of beta-glucan in their laboratory experiments for the purpose of testing substances as immunomodulators without achieving false-positive or negative results. This study aimed to determine the optimum dose of beta-glucan to induce cytokine production by peripheral blood mononuclear cells (PBMCs) in vitro.

Subjects and Method: This was a laboratory experimental study. This study measured the production of two cytokines, including interferon gamma (IFN- $\gamma$ ) and interleukin 12 (IL-12), from the isolated PBMCs of healthy subjects. The doses of beta-glucan used as immunomodulator included 1, 5, 10, 20, and $50 \mu \mathrm{g} / \mathrm{ml}$. Beta-glucan was added to the PBMC culture medium, and the PBMCs were cultured for 6 days. On the sixth day, the supernatant was harvested and the cytokine production was analyzed using sandwich enzyme-linked immunosorbent assay (ELISA). Cytokines were also analyzed using the human IFN- $\gamma$ ELISA kit and the human IL-12 ELISA kit, and data analysis was performed by one-way ANOVA.

Results: IFN- $\gamma$ levels were found to be increased in the group treated with $5 \mu \mathrm{g} / \mathrm{ml}$ beta-glucan.
The highest IFN- $\gamma$ levels (70.0 pg/ml) were observed in the group treated with $10 \mu \mathrm{g} / \mathrm{ml}$ betaglucan. The production of IL-12 increased sharply in the group treated with $5 \mu \mathrm{g} / \mathrm{ml}$ beta-glucan but decreased in the group treated with $10 \mu \mathrm{g} / \mathrm{ml}$ beta-glucan. The mean cytokine levels of the beta-glucan group were found to be significantly different from those of the control group $(\mathrm{p}=0.001)$. One-way ANOVA revealed that the highest IL-12 production $(77.2 \mathrm{pg} / \mathrm{ml})$ occurred at a dose of $5 \mu \mathrm{g} / \mathrm{ml}$ beta-glucan. This average value was significantly different from the average production of IL-12 in the control group $(\mathrm{p}=0.001)$.

Conclusion: The optimum dose of beta-glucan for stimulating PBMCs to produce IFN- $\gamma$ in vitro was $10 \mu \mathrm{g} / \mathrm{ml}$, while for the production of IL-12, the dose was $5 \mu \mathrm{g} / \mathrm{ml}$. Both cytokines can be measured within 6 days of cell culture.

Keywords: beta-glucan, immunomodulator, cytokines

\section{Correspondence: \\ Meira Erawati. Faculty of Medicine, Diponegoro University. Jl. Prof. Soedarto, S.H, Tembalang, Semarang, Indonesia. Email: meiraerawati@- gmail.com. Mobile: +62-81915339685}

\section{Cite this as:}

Erawati M (2020). The Optimum Dose of Beta-Glucan for Stimulating Peripheral blood mononuclear cells (PBMCs) to Produce Cytokines: In Vitro Study. Indones J Med. 5(2): 170-177. https://doi.org/10.26911/theijmed.2020.05.02.12

cc) (i) (9) Indonesian Journal of Medicine is licensed under a Creative Commons EY NG SA Attribution-NonCommercial-ShareAlike 4.o International License.

\section{BACKGROUND}

Cytokines are protein molecules secreted by cells and are involved in intercellular communication, acting as mediators to enhance the immune response through interaction with specific cell surface receptors in leukocytes (Peters, 1996). Immune cells must produce enough cytokines to keep the body heal- 
Erawati et al./ The optimum dose of beta-glucan for stimulating peripheral blood mononuclear cells

thy in cases of both the invasion of pathogenic microorganisms and the occurrence of cell malignancy processes. The occurrence of genetic defects causes less cytokine production, due to which the body becomes susceptible to disease (Ramirez-Alejo and SantosArgumedo, 2014; Bustamantea et al., 2014; Caragol and Casanova, 2003). The primary cytokines that play an important role in fighting bacterial infections are interferon gamma (IFN- $\gamma$ ) and interleukin 12 (IL-12) (Lauw, 2000). IL-12 is a regulatory cytokine that activates natural killer (NK) cells and $\mathrm{T}$ helper 1 (Th1) cells to produce IFN- $\gamma$ (Budak et al., 2008). Meanwhile, IFN- $\gamma$ itself plays an important role in activating the process of phagocytosis and improves protection against intracellular bacterial infections by increasing proactive reactive oxygen species (ROS) (Marchi et al., 2014).

Various substances are known to act as immunomodulators that can stimulate cytokine production. One of the substances used as an immunomodulator is beta-glucan. Utilization of beta-glucan as an immunomodulator developed along with the progress in the concept of complementary alternative medicine or modalities (CAM), which began to develop again in the early 2000s. The research on medicinal mushrooms as a complementary therapy has been widely increasing along with the development of CAM application in the society (Shah et al., 2011). Betaglucan can be extracted from various living things such as yeast, mushroom, barley, and wheat, (Noss et al., 2013; Limberger-Bayer et al., 2014; Goncalves et al., 2014) and it has become one of the substances that has been intensively studied as an immunomodulator in various diseases caused by malignancy or infection processes (Yun et al., 2003; Chan et al., 2009).

Beta-glucan has been used in laboratory experiments as an immunomodulator in both in vivo and in vitro studies (Javmen et al.,
2015, but the effective dose has not yet been determined to measure its performance. Researchers have used different doses of beta-glucan in their experiments. Like other immunomodulators, it is necessary to establish an appropriate dose for use in laboratory experiments, so that the research objectives can be achieved without positive-false or -negative results.

Therefore, the aims of this study were to determine the optimum dose of beta-glucan to induce cytokine production by peripheral blood mononuclear cells (PBMCs) in vitro and to provide basic research data and a scientific basis for its application in laboratory assessment.

\section{SUBJECTS AND METHOD}

\section{Study Design}

This was a laboratory experimental study that compared the effects occurring in the treatment group and the control group.

\section{Population and Sample}

In this study, PBMCs isolated from healthy donors were used as the research subject. The inclusion criteria of the subjects were as follows: healthy men or women aged 18-25 years, showing negative test results for HIV, hepatitis $\mathrm{B}$, and hepatitis $\mathrm{C}$ screening (conducted at RSU Banyumanik Semarang), and not taking immunosuppressant or immunomodulators. Before participation in the study, the subjects were briefed about the study and agreed to be involved in the research by signing the informed consent form.

\section{Study Variables}

The dependent variable was cytokines production. The independent variable were doses of beta-glucan for Stimulating PBMCs.

\section{Operational Definition of Variables} Isolation and Culture of PBMCs were carried out according to the following steps. A total of $4 \mathrm{ml}$ of peripheral blood of subjects was collected into a heparin lithium tube (Endo Vacu Tube) and allowed to stand for 
Erawati et al./The optimum dose of beta-glucan for stimulating peripheral blood mononuclear cells

$60 \mathrm{~min}$ at room temperature. The tube was then centrifuged at $1500 \mathrm{rpm}$ for $15 \mathrm{~min}$. Then, Ficoll (Amersham Ficoll-Paque PLUS) was added to the tube and centrifuged at 1500 rpm for $15 \mathrm{~min}$. The buffy coat was collected and washed twice with PBS. In the PBMC tube, $1 \mathrm{ml}$ of complete RPMI medium was added, and the cells were counted under a microscope using a hemocytometer. PBM$\mathrm{Cs}(5 \times 105 / \mathrm{ml})$ were cultured in 24-well plates containing the complete RPMI medium as the control group and in plates containing the RPMI medium added with beta-glucan at various doses, including $1,5,10,20$, and 50 $\mu \mathrm{g} / \mathrm{ml}$, as the treatment groups. Subsequently, the cells were incubated in a 5\% CO2 incubator at $37^{\circ} \mathrm{C}$ for 6 days.

Beta-Glucan of manufactured baker's yeast Saccharomyces cerevisiae was used. Before use, beta-glucan was dissolved in ultrapure water and vortexed for $15 \mathrm{~min}$.

Measurement of Cytokines (IFN- $\gamma$ and IL-12) were assessed in this study. On the sixth day, the supernatant was collected and the cytokine production was determined using sandwich enzyme-linked immunosorbent assay (ELISA). The cytokines were further analyzed using the human IFN- $\gamma$ ELISA kit and the human IL-12 ELISA kit according to the manufacturer's instructions. The collected supernatant was centrifuged at 1000 $\mathrm{rpm}$ for $20 \mathrm{~min}$. Before use, the plate was rinsed twice. The standard and a sample of $100 \mu \mathrm{l}$ were collected into each well and incubated at $37^{\circ} \mathrm{C}$ for 90 min. Furthermore, $100 \mu \mathrm{l}$ of biotin-detection antibody working solution was added to each well and incubated at $37^{\circ} \mathrm{C}$ for $60 \mathrm{~min}$. The plate was washed three times. Into each well of the plate, $100 \mu \mathrm{l}$ of SABC working solution was added and incubated at $37^{\circ} \mathrm{C}$ for $30 \mathrm{~min}$. The washing step was performed five times. Then, $90 \mu \mathrm{l}$ of TMB substrate was added and incubated for $15 \mathrm{~min}$ at $37^{\circ} \mathrm{C}$. In the next step, $50 \mu \mathrm{l}$ of stop solution was added, and the cytokine levels were read on a micro plate reader at an optical density (OD) of $450 \mathrm{~nm}$ absorbance.

\section{Data Analysis}

The normality of data was assessed using the Kolmogorov-Smirnov test, while the comparison between treatments was done using one-way ANOVA. Data were displayed and analyzed using Microsoft Excel 2010 and IBM SPSS Statistics 20, with the significance level set at $\mathrm{p}<0.05$.

\section{Research Ethic}

This study was conducted with the approval of the Committee on Ethical Research for Health of the Faculty of Medicine, Diponegoro University, and the Kariadi Hospital, Semarang, Indonesia. Ethical clearance for this project is available under the registration no. 467/EC/FK-RSDK/VII/2017 at the secretariat of the Committee on Ethical Research for Health of the Faculty of Medicine, Diponegoro University, and the Kariadi Hospital. Laboratory tests were conducted at the Parasitology Laboratory of the Faculty of Medicine, Gadjah Mada University, Yogyakarta, from March to April 2018.

\section{RESULTS}

The production of IFN- $\gamma$ and IL-12 was measured in the six PBMC groups, including the control group and the groups treated with $1,5,10,20$, and $50 \mu \mathrm{g} / \mathrm{ml}$ of beta-glucan. Figure 1 shows the results of IFN- $\gamma$ and IL-12 measurements for the treatment and the control groups. IFN- $\gamma$ levels were increased in the PBMC group cultured with the addition of beta-glucan from the dose of $5 \mu \mathrm{g} / \mathrm{ml}$ till the dose of $10 \mu \mathrm{g} / \mathrm{ml}$, at which the highest IFN- $\gamma$ level was detected. In addition, at the subsequent dose $(20 \mu \mathrm{g} / \mathrm{ml})$, the IFN- $\gamma$ level began to decrease. The PBMC group treated with $50 \mu \mathrm{g} / \mathrm{ml}$ beta-glucan also showed a decrease in IFN- $\gamma$ level. 
Erawati et al./ The optimum dose of beta-glucan for stimulating peripheral blood mononuclear cells

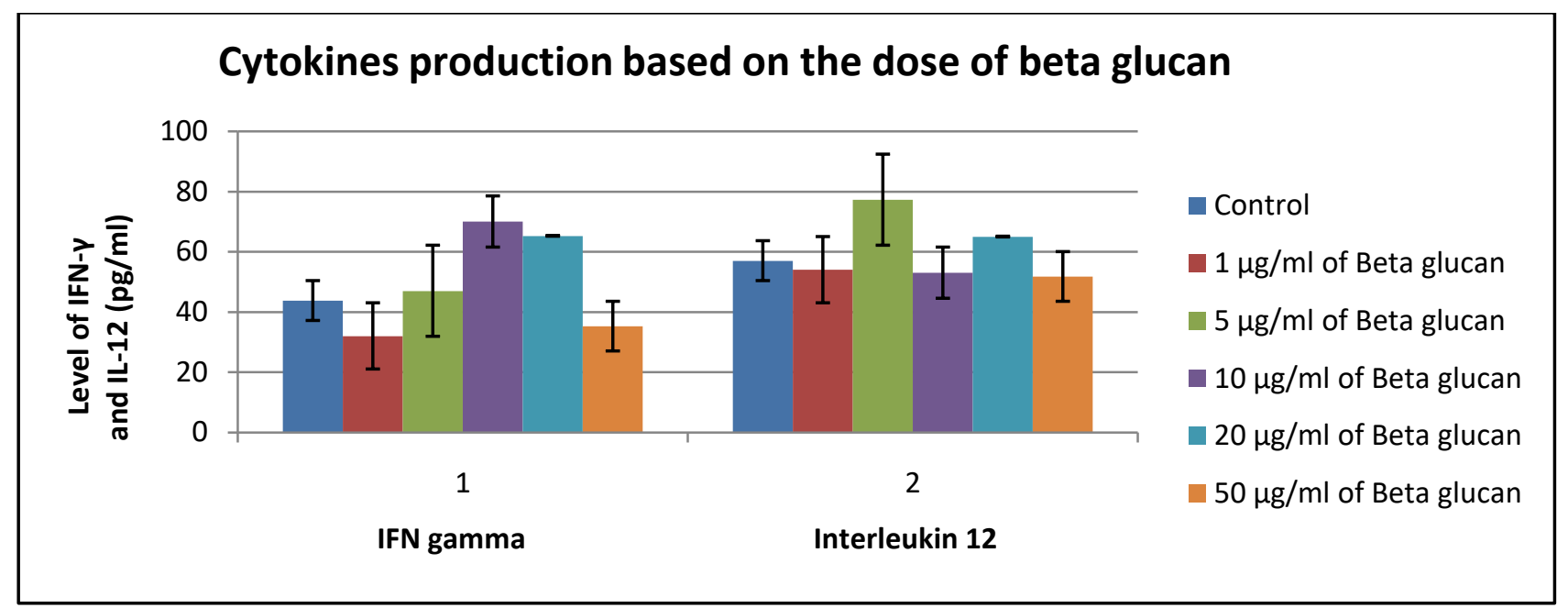

\section{Figure 1. Cytokine production by PBMCs in control group and treatment groups}

Meanwhile, the highest level of IL-12 production was detected in the group treated with $5 \mu \mathrm{g} / \mathrm{ml}$ beta-glucan. In the PBMC cultures treated with $10 \mu \mathrm{g} / \mathrm{ml}$ beta-glucan, the IL-12 production was decreased, but at the dose of $20 \mu \mathrm{g} / \mathrm{ml}$ beta-glucan, the IL-12 levels started to elevate. However, at the dose of $50 \mu \mathrm{g} / \mathrm{ml}$, the levels of IL-12 decreased again.To determine the optimum dose of beta-glucan to be used as an immunomodulator, the normality was assessed using the Kolmogorov-Smirnov test, which showed that both IFN- $\gamma$ and IL-12 data were normally distributed. Furthermore, one-way ANOVA was conducted to determine the difference in the mean production of both cytokines under various treatments. The results of both tests are presented in Table 1.

Table 1. The mean distribution of IFN- $\gamma$ and IL-12 data according to the dose of betaglucan

\begin{tabular}{lcccc}
\hline Variable & Dose of beta-glucan $(\boldsymbol{\mu g} / \mathbf{m l})$ & Mean $(\mathbf{p g} / \mathbf{m l})$ & SD & p \\
\hline IFN- $\gamma$ & 0 & 43.7 & 0.35 & 0.001 \\
& 1 & 32.0 & 4.24 & \\
5 & 47.0 & 5.65 & \\
& 10 & 70.0 & 1.41 & \\
IL-12 & 20 & 65.2 & 1.76 & \\
& 50 & 35.2 & 1.06 & \\
& 0 & 57.0 & 2.28 & 0.001 \\
& 1 & 54.0 & 1.41 & \\
& 5 & 77.2 & 1.76 & \\
& 10 & 53.0 & 2.12 & \\
& 20 & 65.0 & 1.41 & \\
\hline
\end{tabular}

The ANOVA showed that the highest IL-12 production $(77.2 \mathrm{pg} / \mathrm{ml})$ occurred at the dose of $5 \mu \mathrm{g} / \mathrm{ml}$ beta-glucan. This average value was significantly different from the mean value of IL-12 production in the control group $(\mathrm{p}=0.001)$.

\section{DISCUSSION}

The concept of CAM describes that biologically based therapies use typically natural substances and include herbs and essential oils, special diets, nutritional and food supplements, and other products (Kramlich, 2014) such as beta-glucan. Along with the CAM 
concept, the results of this study show that the beta-glucan extracted from the yeast $S$. cerevisiae can be used as an immunemodulator, particularly acting as a stimulator of IFN- $\gamma$ and IL-12 production in vitro. There are various types of glucan molecules that can be extracted from various sources, including mushrooms, yeast, wheat, and other plants. The potential of glucan as an immunomodulator is determined by its structure and molecular weight (Choromanska et al., 2018).In this study, the beta glucan used as immunomodulator was derived from $S$. cerevisiae because of the structure of $\beta-(1,3)$ $(1,6)$-glucan and molecular weight $(35-5000$ $\mathrm{kDa}$ ), this glucan indicates its potential to be used as an immunomodulator, particularly to induce the production of cytokines by immune cells (Noss et al., 2013).

Certain substances can affect the physiology of the body at the right dosage. Administering substances in quantities that are too small cannot produce the expected effect, but administering excessive quantity will also have an impact on the occurrence of toxicity to targeted cells or organs. To obtain the right dose according to the expected goals, researchers must test various doses repeatedly, especially for new substances that are not yet widely known. Several previous studies have shown that the potential of beta-glucan as an immunomodulator depends on the given dose. Some of the cytokines that can be stimulated by beta-glucan include IFN- $\gamma$, IL-12 (Budak, 2008), TNF- $\alpha$, IL-6, and IL-8 (Noss et al., 2013).

In this study, compared with the control group and other beta-glucan doses, the highest production of IFN- $\gamma$ was observed in PBMCs treated with $10 \mu \mathrm{g} / \mathrm{ml}$ beta-glucan for 6 days, whereas the highest production of IL12 was detected in PBMCs treated with 5 $\mu \mathrm{g} / \mathrm{ml}$ beta-glucan for 6 days. These results are slightly different from those of previous studies using a single dose of $5 \mu \mathrm{g} / \mathrm{ml}$ beta- glucan to obtain the immunomodulator effects of PBMCs on both IFN- $\gamma$ and IL-12 production (Budak et al., 2008).

Beta-glucan is administered at differrent doses and times according to the desired goal. In rats infected with influenza virus, beta-glucan may reduce the risk of death from infection at a dose of $881.5 \mu \mathrm{g} /$ day for 12 days by preventing massive weight loss, stimulating the ability of phagocytosis by mouse peripheral blood neutrophils, and killing by NK cells, as well as by increasing the production of several cytokines such as IFN- $\gamma$, IL- $1 \beta$, and TNF- $\alpha$ (Vitvicka et al., 2015). Other experiments were performed on mice with polymicrobial infection. After $1 \mathrm{~h}$ of infection, mice were administered $10 \mathrm{mg} / \mathrm{kg}$ of body weight of PGG glucan. After $6 \mathrm{~h}$, the cytokines were measured in blood samples. Results showed that the PGG glucan enhanced the survival in female mice over a 10-day period, but survival in males was improved for only $24 \mathrm{~h}$. In female mice, PGG glucan reduced the levels of IL- 6 and IL-10 and also reduced the bacterial burden in the liver (Newsome et al., 2011).

In addition to its use to boost the immune host system during infection, beta-glucan is often used to enhance the immune system in malignancy. Beta-glucan extracted from $S$. cerevisiae has growth inhibitory effects against the murine mammary adenocarcinoma AMN-3 cell line depending on time and concentration. The highest effect was obtained with the beta-glucan extract at higher concentrations after $48 \mathrm{~h}$ of exposure in the AMN-3 cell line (Jabber et al., 2011).

In patients with prostate cancer who were administered 20mg of soluble betaglucan in the form of a carboxymethylated (CM-G) capsule daily for 28 days, the total leukocyte count increased significantly $(\mathrm{p}=$ 0.02), with no associated changes in the lifestyle habits of the patients. A significant increase $(p=0.001)$ was also observed in red 
Erawati et al./ The optimum dose of beta-glucan for stimulating peripheral blood mononuclear cells

blood cell, hematocrit, hemoglobin, and platelet counts. No changes were observed in the hepatic or renal function after CM-G administration, and there were also no side effects associated with its use (Magnani et al., 2010).

In addition to improving the fitness of immune cells so that they can function optimally, one of the mechanisms of beta-glucan to help the body fight against malignancy is by activating immune responses to induce cell apoptosis through the caspase-3-dependent signaling pathway and to inhibit cell proliferation possibly via the $\mathrm{p} 53$-dependent signaling pathway in vivo. Besides, it has been reported that LNT inhibited angiogenesis by suppressing VEGF expression, leading to slow progression of tumors (Xu et al., 2016).

This study demonstrated that the global cytokine production in the beta-glucan group was increased significantly $(p<0.05)$. The optimum dose of beta-glucan for stimulating PBMCs to produce IFN- $\gamma$ in vitro was 10 $\mu \mathrm{g} / \mathrm{ml}$, while it was $5 \mu \mathrm{g} / \mathrm{ml}$ to induce the production of IL-12 by PBMCs. Both cytokines can be measured on the sixth day of cell culture. These findings suggest that beta-glucan is useful as a complementary or adjuvant therapy for improving the production of cytokines.

\section{AUTHOR CONTRIBUTION}

Meira Erawati conducted the study, collected the data, analyzed the results, and wrote the article.

\section{CONFLICT OF INTEREST}

There is no conflict of interest in this study.

\section{FUNDING AND SPONSORSHIP}

This research was carried out with financial assistance from the Ministry of Research, Technology, \& Higher Education of the Republic of Indonesia 2018.

\section{ACKNOWLEDGEMENT}

The author give gratitude toward Ministry of Research, Technology, \& Higher Education of the Republic of Indonesia for the funding and also thankful for every help from every party in this study.

\section{REFERENCE}

Budak F, Goral G, Oral HB (2008). Saccharomyces Cerevisiae Beta-Glucan Induces Interferon-Gamma Production in Human T Cells Via IL-12. Turk J Immunol. 13: 21-6.https://doi.org/10.18585/inabj.v11i2.688

Bustamantea J, Boisson-Dupuisa S, Abela L, Casanova J (2014). Mendelian susceptibility to mycobacterial disease: genetic, immunological, and clinical features of inborn errors of IFN- $\gamma$ immunity. SeminImmunol.26: 454-70.https://doi.org/10.1016/j.smim.2014.09.008

Caragol I, Casanova JL (2003). Inherited disorders of the Interleukin-12/Interferon-gamma axis: Mendelian predisposition to mycobacterial disease in man. Inmunología.22: 263-76. Retrieved from https://www.inmunologia.org/Upload/Articles/6/o/601.pdf

Chan GC, Chan WK, Sze DM (2009). The effects of $\beta$-glucan on human immune and cancer cells. J HematolOncol. 2:111.https://doi.org/10.1186/1756-87222-25

Choromanska A, Kulbacka J, Harasym J, Oledzki R, Szewczyk A, Saczko J (2018). High- and low-molecular weight oat beta-glucan reveals antitumor activity in human epithelial lung cancer. PatholOncol Res. 24:583-92. https://doi.org/10.1007/s12253-0170278-3

Goncalves MAD, Dritz SS, DeRouchey JM, Tokach MD (2014). Effects of algaederived $\beta$-glucans with zinc onnursery pig growth performance and immune- 
Erawati et al./The optimum dose of beta-glucan for stimulating peripheral blood mononuclear cells

response under commercial conditions. Kansas Agricultural Experiment Station Research Reports.https://doi.org/10.4148/2378-5977.6913

Jabber AJ, Mahdi NR, Yaseen NY (2011). The Effect of Beta Glucan Extract of Saccharomyces cerevieses on Cancer Cell Growth In vitro. Iraqi Journal of Cancer and Medical Genetics. 4:54-8. Retrieved from http://ijcmg.uomustansiriyah.edu.iq/index.php/ijcmg/article/view/79

Javmen A, Nemeikaite-Ceniene A, Bratchikov MB, Grigiskis S, Grigas F, Jonauskiene I, et al (2015). $\beta$-Glucan from $\mathrm{Sa}$ ccharomyces cerevisiae Induces IFN- $\gamma$ Production In Vivo in BALB/c Mice. In vivo. 29: 359-64. Retrieved from https://www.ncbi.nlm.nih.gov/pubmed/259 77381

Kramlich D (2014). Introduction to Complementary, Alternative, and Traditional Therapies. Crit Care Nurse. 34: 506.https://doi.org/10.4037/ccn2014807

Lauw FN (2000). IL-12, IL-18 and IFNgamma in the immune response to bacterial infection. UvA-DARE (Digital Academic Repository) University of Amsterdam.: 18-26. Retrieved from https://dare.uva.nl/search?identifier=a 3d78cf8-32fa-4e21-b67a-5c8a3d9aa655

Limberger-Bayer VM, Francisco A, Chan A, Oro T, Ogliari PJ, Barreto PLM (2014). Barley b-glucans extraction and partial characterization. Food Chem. 154:849.https://doi.org/10.1016/j.foodchem.2013.12.104

Magnani M, Castro-GomEz RH, Aoki MN, Gregório EP, LibosJrF, Watanabe MA B (2010). Effects of carboxymethyl-glucan from Saccharomyces cerevisiae on the peripheral blood cells of patients with advanced prostate cancer. Exp Ther Med. 1: 859-62.https://dx.doi-
.org/10.1590\%2FS1415-47572010005000103

Marchi LF, Sesti-Costa R, Ignacchiti MDC, Chedraoui-Silva S, Mantovani B (2014). In vitro activation of mouse neutrophils by recombinant human interferongamma: Increased phagocytosis and release of reactive oxygen species and pro-inflammatory cytokines. Int Immunopharmacol.18:228-35.https://doi.org/10.1016/j.intimp.2013.12.010

Newsome CT, Flores E, Ayala A, Gregory S, Reichner JS (2011). Improved Antimicrobial Host Defense in Mice following Poly-(1,6)--D-Glucopyranosyl-(1,3)--DGlucopyranose Glucan Treatment by a Gender-Dependent Immune Mechanism. Clin Vaccine Immunol. 18: 2043-9. https://doi.org/10.1128/CVI.05202-11

Noss I, Doekes G, Thorne PS, Heederik DJJ, Wouters I W (2013). Comparison of the potency of a variety of $\beta$-glucans to induce cytokine production in human whole blood. Innate Immun. 19:1019.https://doi.org/10.1177/1753425912 447129

Peters M (1996). Actions of Cytokines on the Immune Response and ViralInteractions: An Overview. Hepatology. 23: 909-16.https://doi.org/10.1053/jhep.1996.v23.ajhepo230909

Ramirez-Alejo N, Santos-Argumedo L (2014). Innate Defects of the IL-12/IFN-g Axis in Susceptibility to Infections by Mycobacteria and Salmonella. J Interferon Cytokine Res. 34:30717.https://doi.org/10.1089/jir.2013.o050

Shah SK, Walker PA, Moore-Olufemi SD, Sundaresan A, Kulkarni A, Andrassy RJ (2011). An Evidence-Based Review of a Lentinulaedodes Mushroom Extract as Complementary Therapy in the Surgical Oncology Patient. J Parenter En- 
Erawati et al./ The optimum dose of beta-glucan for stimulating peripheral blood mononuclear cells

teral Nutr. 35:449-58.https://doi.org/10.1177/0148607110380684

Vetvicka V, Vetvickova J (2015). Glucan supplementation enhances the immune response against an influenza challenge in mice. Ann Transl Med.3:1-7.https://dx.doi.org/10.3978\%2Fj.issn.23055839.2015.01.08

$\mathrm{Xu} \mathrm{H}$, Zou S, Xu X, Zhang L (2016). Antitumor effect of $\beta$-glucan from Lentin use dodes and the underlying mechanism. Nature Scientific Reports. 6:1-13. https://doi.org/10.1038/srep28802

Yun C-H, Estrada A, Van Kessel A, Park BC, Laarveld B (2003). L-Glucan, extracted from oat, enhances disease resistance against bacterial and parasitic infections. FEMS Immunol Med Microbiol. 35:67-75.https://doi.org/10.1016/So928-8244(02)00460-1 